See discussions, stats, and author profiles for this publication at: https://www.researchgate.net/publication/320153329

\title{
The ironies of new innovation and the sunset industry: Diffusion and adoption
}

Article in Journal of Rural Studies · October 2017

DOI: 10.1016/j.jurstud.2017.07.015

\section{CITATIONS}

16

4 authors, including:

(69).

hahrina Md Nordin

Universiti Teknologi PETRONAS

54 PUBLICATIONS 532 CITATIONS

SEE PROFILE

8. Ammar Redza

University Malaysia Sarawak

9 PUBLICATIONS 36 CITATIONS

SEE PROFILE
101

Shameem Rafik-Galea

Galileo Enterprises and Consultancy Services

9 PUBLICATIONS 37 CitATIONS

SEE PROFILE

Some of the authors of this publication are also working on these related projects:

http://www.igi-global.com/book/applied-behavioral-economics-research-trends/166083 View project

Master's project View project 


\title{
The ironies of new innovation and the sunset industry: Diffusion and adoption
}

\author{
Sobia Mannan a, *, Shahrina Md Nordin a, Shameem Rafik-Galea ${ }^{\text {b }}$, \\ Ammar Redza Ahmad Rizal ${ }^{\text {a }}$ \\ a Universiti Teknologi PETRONAS, Bandar Seri Iskandar, Tronoh, Perak, Malaysia \\ b Universiti Putra Malaysia, Jalan Upm, 43400 Serdang, Selangor, Malaysia
}

\section{A R T I C L E I N F O}

\section{Article history:}

Received 29 August 2016

Received in revised form

26 May 2017

Accepted 19 July 2017

\section{Keywords:}

Innovation diffusion

Paddy rice

Fertilizer

Adoption

\begin{abstract}
A B S T R A C T
Agriculture plays a vital role in the Malaysian economy. Within the agriculture sector, paddy is considered important as it is the staple food for the nation. Innovation is considered as an important and necessary component in the development of agricultural activities, while communication is the powerful tool to further strengthen this sector. Technology adoption would only take place if innovation is driven by farmers' need. Innovation diffusion technology transfer and adoption are all inter-related facets in increasing crop production. This study examined the influence of innovation attributes, communication channels and awareness in aiding diffusion and adoption of green fertilizer technology innovation in paddy farming in Malaysia. Past innovation diffusion studies have had limited emphasis on the importance of communication for diffusion and adoption of green fertilizer technologies. Hence, there exists a gap that demands specific studies to be undertaken. This study adopted a quantitative method through survey dissemination to fulfil the aim and objective of this study. 366 paddy farmers were selected from Perak to be the respondents. Demographic and multiple regression analysis were carried out on the data. Examining these results is an important first step toward understanding factors that could make the paddy sector in Malaysia more sustainable. From the analyzed data, this study found that certain attributes which are compatibility, interpersonal communication, mass media and awareness have an influence on green fertilizer technology adoption among the local farmers in Malaysia. The results indicate that the level of farmers awareness and information about innovation in general, innovation diffusion process and the extent of attributes in innovation. The study have several implications for government agencies and policy makers in the agricultural sector. Impact of study on Malaysian context are also proposed.
\end{abstract}

ㄷ) 2017 Published by Elsevier Ltd.

\section{Introduction}

In Malaysia, paddy rice is one of the most important agricultural crops besides oil palm and rubber, which is grown in both peninsular and East Malaysia. About 300,500 ha in peninsular Malaysia and 190,000 ha on Borneo Islands are designated for rice production (Haris et al., 2013). While, the total annual production of rice stands at 2.7 million metric tons (FAOstat, 2015). Rice cultivation area (rice bowl) is divided into two parts: the irrigated scheme and non-irrigated scheme. It is reported that Irrigated scheme could achieve higher yield as compared to the non-irrigated scheme

\footnotetext{
* Corresponding author.

E-mail address: sobiamannan@gmail.com (S. Mannan).
}

(DOA, 2012). The management of the rice production in the rice bowl area is called Integrated Agricultural Development Authority (IADA). According to Ministry of Agriculture and agro-based industry (MOA), IADA is the main producer that meets $72 \%$ of the demand of this country (MARDI, 2010). During the economic crisis in 2007, Asian countries including Malaysia turned to agriculture as one of their main income generators. Due to its strength in terms of shaping the socio-economic development of the community, agriculture has been mentioned in every Malaysian Plan as having brought more money into the country and the local community. In the Ninth Malaysian Plan (RMK-9), agriculture is declared as the third largest income generator for Malaysia. Therefore, a great deal of effort is needed to ensure that the agriculture sector can elevate the economic development of Malaysia.

Agriculture is the major driving source of Malaysian livelihood. 